Clinton Bailey (Israel) - The Translation of Bedouin Poetry from Sinai and the Negev.

Robert D. MCChesney (NYU) - Translation of Siraj al-Tawarikh (Annals of Afghan istan, 1880-1897).

Grace M. Smith (Berkeley, Ca)-Translation of the "Divan" of Yunus Emre: Annotated Translation of the Poetry of Turkey's 14 th Century "National Poet."

Karl Stowasser (U. of Maryland)-The Story of Medieval Egypt: al-Maqrizi's Topographical History

Bernard G. Weiss (Lewiston, NY)-Translation of Al-Amidi's Questions and Answers in Islamic Jurisprudence.

\title{
NEWS FROM GREAT BRITAIN
}

The following information was $k$ indly supplied by Robin Bidwell, University of Cambridge; R.I. Lawless, University of Durham; J.T. Suddaby and L.P. Elwell-Sutton, University of Edinburgh; D.E.P. Jackson, University of St. Andrews.

\section{PH.D's Completed}

C.D. Holes-University of Cambridge: A Sociolinguistic Study of the Arabic-Speaking Speech-Community of Bahrain: Language Variation in Relation to Sect-Membership, Religion and Literacy.

Mahmoud Abdullah Jaffal-University of Cambridge: Arabic Philological Studies in the 4th Century AH/10th Century AD, Their Origin and Development.

Khalid Karaki-University of Cambridge: From Islamism to Arabism: A Study of the Political Ideas of Syrian Writings 1918-1952.

M.G. Mian-University of Durham: Spatial Patterns of Population Growth and Agricultural Change in the Punjab, Pakistan, 1901-72.

W.G. Rigden-University of Durham: Afar, Ethiopia: a Local Seismic Survey.

I.C. Harrison-University of Durham: Integrated Rural Development in a Case Study of Monastir Governorate Tunisia.

S.Y. Seyedna-University of Durham: A Genetic and Demographic Study of the Zoroastrians of Iran.

M.H. Whitton--University of Durham: An Analysis of Land Use and Water Use Patterns of the Esfahan Region.

A.E. Yücel-University of Durham: Turkish Migrant Workers in the Federal Republic of Germany: An Anthropological Study of Migration.

Parinaz Shahnevaz-University of Edinburgh: The Struggle for Supremacy between the Zands and the Qajars, 1193-1209/1779-1794: A Society in Transition.

Ahmad Taheri-University of Edinburgh: Zandaqa in the Early $\mathrm{C}_{\mathrm{Abb}}$ asid Period with Special Reference to Poetry.

Robert Wells-University of Edinburgh: Jalāi Āle Ahmad, Writer and Political Activist.

Bernard L.P. O'Kane-University of Edinburgh: Timurid Architecture in Khurasan.

Abdul-Rahman S. Abdullah-University of Edinburgh: Educational Theory: A Qur'ānic Outlook.

Jasim Sagbain Ali-University of Edinburgh: The Christians of the Jazíra 17-132 A.H./638-750 A.D. 
Sükrï Selim Has-University of Edinburgh: A Study of Ibrāhīm al-Halabī with Special Reference to the Multaqã.

Necati Öztürk - University of Edinburgh: Islamic Orthodoxy Among the ottomans in the Seventeenth Century with Special Reference to the Qadi-zade Movement.

Hasanat Satti-University of Edinburgh: A Translation of and Introduction to al-Amr bi-'I-macruf wa-'l-nahy $C_{a n}$ al-munkar by Ibn Taymiyya.

Dhia M. Siddeek - University of Edinburgh: Romanticism and Realism: $A$ Study in the Novels of Yusuf as Sibāç.

Mohammad A.S. Siddiqui-University of Edinburgh: A Study of the Evolution of ijtihäd (legal reasoning) in the Development of the zakst law during the 1 st century A.H.

Adnan Wazzan-University of Edinburgh: Realism in Arnold Bennett and Najtb Mahfuz: a Comparative Study in the Arabic and the English Novel.

Azar Youssef-Jamali-University of Edinburgh: The Status of Women in an Äzarbāyjāni Village (Iran) with Special Reference to Carpet Manufacture.

Mohommad K. Youssef-Jamali-University of Edinburgh: The Life and Personality of Shah Ismācĩ I (1487-1524).

Kamel Khalil Zaghmoot-University of Edinburgh: A Critical Edition of Some Early Works of Tradition, Together with an Introduction and Analysis of these Works.

Shaukat Mahmood-University of Edinburgh: Islamic Inscriptions in Pakistani Architecture to 1707.

A.I. Ilyas-University of St. Andrews: Linguistic and Extra-Linguistic Problems in the Translation of the Holy Qur'än.

Ph.D's in Progress

Ahmed A. Ahmed-University of Cambridge: The Role of Students in Egyptian National Politics 1945-73.

I. Badruddin-University of Cambridge: A Critical Discussion on the Source Material for the Transfer of the Fatimi Da'wah from the Yemen to India.

Y.M. Chouairi-University of Cambridge: The Struggle Between $\mathrm{C}_{\mathrm{Al}} \mathrm{I}$ and MuCawiya in Modern Arabic Thought.

Ildiko Ebeler-Hann-University of Cambridge: The Embassy to Cathay Sent by Shahnukh.

I.H. Huse in-University of Cambridge: The Role in the Tribe of Tamin in Politics and Political Poetry in the Eastern Muslim Provinces from the Rise of Islam to the End of the Umayyad Period.

T.M.S. Al-Khalidi-University of Cambridge: Public Expenditure Policy in Iraq.

Ahmad S.S. Oweidi-University of Cambridge: The Bedouin Judicial Processes in Jordan.

Akaa El-Salem-University of Cambridge: Literary Criticism and Rhetoric in the 6 th and 7 th Centuries A.H., with Special Reference to AlZanjani's MiCyar Al-Nuzzar.

Jamila Shaukat-University of Cambridge: A Critical Edition of Musnad ${ }^{C} A C$ ishah from the Rahuwain's Musnad, with an Account of the Author and of Women Transmitters of Hadith.

A.A. Zainal Abidin-University of Cambridge: The Ulama in Eighteenth Century Arabia.

Mohammed Abdullah Al-Zulfa-University of Cambridge: Asir and the 0ttoman Empire in the 19th Century.

B.E.Y.M.Ahmed-University of Durham: Climatology-Sudan.

P.Amirshahi-University of Durham: Bio-anthropological Studies of Iran Populations. 
H.B.A. Al-Amri-University of Durham: Muhammed b. Ali al-Shawkani, The Great Yemeni Scholar 1758-1834.

J. Bennet-University of Durham: Notion of Ethnicity Among Refugees in the Sudan.

F.H. Besseisu-University of Durham: Regional Development Collaboration.

F.M. El-Essawy-University of Durham: Population of Food Resources.

G. Falah-University of Durham: Bedouin in Galilee.

A. Finkel-University of Durham: Formation of the Working Class in the Turkish City of Izmit.

B. Al-Goblan-University of Durham: Political Economy of Saudi Arabia.

T. Holman--University of Durham: A Study of Artistic and Craft Production in Turkey.

F. Jamali-Zanjeerabad--University of Durham: Inter-provincial Migration in Azarbaijan.

0 . Jastiniah-University of Durham: Urban Geography of Jiddah.

I.J.M. Jawad-University of Durham: Crop Yields, Climate and Weather in Iraq.

S.K. Kezeiri-University of Durham: Small Towns in Libya.

M.A. Al-Kubaisi-University of Durham: Industrial Development in Qatar, 1950-1970s.

K.A. Kumosani-University of Durham: Built Environment of Jiddah.

G. Lauder-University of Durham: Political Violence and Social Change: A Study of the Palestinian Arab.

A.M.A. Al-Medej-University of Durham: The Reign of the Abbasid Dynasty $750-1258$.

A. Mermer-University of Durham: Religious Movement in Contemporary Turkey.

S. Al-Misnad-University of Durham: The Education of Women in Qatar.

B.S. Al-Najjar-University of Durham: The Sociology of Labour Ph.D. Migration: A Case Study of Kuwait.

Y.M. Nasser-University of Durham: Planning in Yemen.

G.J. Roper-University of Durham: Printed Books and the Dissemination of Knowledge in Egypt in the Nineteenth Century.

I.J. Secombe-University of Durham: Labour Migration in Jordan.

A.M.J. Al-Siraih-University of Durham: Basrah and Region.

K.A.0. Uqbah-University of Durham: Agricultural Development in U.A.E.

M. Weld--University of Durham: The Concept of Shaha'dat in Shi'ism since the 16th Century - the Case for Iran.

A.0. Al-Zelaie-University of Durham: Makkan Yemeni Relations Ph.D. in the Rasuli Age.

Ahmed Ali Mohammed Abdalla-University of Edinburgh: The Variant Readings of the Qur'an: A Critical Study of Their Historical and Linguistic Origins.

Mahmoud Abdullahzadeh-University of Edinburgh: Iran's Foreign Policy Adoption from the Inception of the Second World War to the Azarbaijan Crisis.

Qibla Ayaz-University of Edinburgh: The Akhbār al-Dawla Al-Saljuqiyya of al-Husayni: an Unexploited Source for the History of the Saljuq Period:

Husain al-Dhawwad-University of Edinburgh: The al-Nukat al-Hisān of Abu Hayyān: A Critical Edition with an Introductory Study.

Fadhl Ammar al-Dousary-University of Edinburgh: Poetry of Taghlib.

Abdallah A. Drees-University of Edinburgh: The Social and Economic Life of Medina in the Period of the First Two Caliphs.

Osman Mohamed Eid-University of Edinburgh: Elementary Education in Islam.

Iraj Emami-University of Edinburgh: The Iranian Theatre.

Ahmad Ibrahim al-Fagih-University of Edinburgh: The Libyan Short Story 1950-1975. 
Mesfer al-Harithi-University of Edinburgh: The al-Fara'id al-Wafiyya bi-Dhikr ma lam Tahwihi al-Alfiyya of al-Mansürt: A Critical Edition with a Comparative Study Between it and the Alfiyya of Ibn Malik.

Salman Mohsin Hassan-University of Edinburgh: The Principles of Islamic Jurisprudence in the Work of al-Mürțada.

Cheng Hsiang Hsu-University of Edinburgh: A Study of Arabic Printed Literature in Egypt from the Beginning until 1882 A.D.

Husse in Yousif Hussein-University of Edinburgh: A Comparative Study of the Historical Novels of Walter Scott and Jurji Zaydān.

Javad Karandish-University of Edinburgh: The Resettlement of the Tribes During the Reign of Reza Shah.

Najleh Khandagh-University of Edinburgh: Political Parties in Iran from 1941 to 1947, with Special Reference to the Democratic Party of Azarbaijan.

Arzina Lalani-University of Edinburgh: The Life and Career of Imam Muhammad al-Băqir.

Mohammed el-Mahdi-University of Edinburgh: The Utilitarian Trends in Ibn Miskawayh's Ethics.

Suran Mardini-University of Edinburgh: The Concept of the Islamic uma in the Qur'än.

Ahmed Abdel Rahman Mohammed-University of Edinburgh: Aspects of Muslim Administration in the Umayyad Caliphate.

Mohammed Jabbar Muaibed-University of Edinburgh: A Historical Study of the dad.

Rafiu Omotosho--University of Edinburgh: The Problem of al-Amr among the Usulis.

Arssan Mussa Rashid-University of Edinburgh: The role of the shurţa in Early Islam.

Philip Sadgrove-University of Edinburgh: The Genesis, Evolution and Influence of the Literary Press in Egypt up to the British Occupation (1798-1882.).

Durreshahwar Sayed-University of Edinburgh: Shah Abdul Latif and Sachal Sarmast: Two Sufis and Poets of Sind.

Mohammad Suleman-University of Edinburgh: Intelligence-Gathering During the Time of the Prophet.

Mohammad Tabatabai-University of Edinburgh: Shaykh Muhammad KhTyabant and his Role in the Socio-Political Movement in Iran, 1910-1920.

David Nicolle-University of Edinburgh: The Military Technology of Classical Islam.

Marzouk Tenbak - University of Edinburgh: Social Development and its Influence on Political Poetry in the Early Umayyad Period.

Frances Abercromby-University of St. Andrews: The Writings of Laila Ba' labakki.

M.M. Ahmed-University of St. Andrews: A Critical Edition of Sharh Diwan al-Mutanabbi by Ibn Jinni.

Hana S. Al-Hubaity-University of St. Andrews: Simile in the Qur'an.

S.K. Al-Jamil-University of St. Andrews: A Critical Edition of Al Durr Al Maknūn Fi Al Ma'athir Al Mădi Min Al Qurūn by Yasin Al Omari.

J.A. Al-Jomard-University of St. Andrews: A Critical Edition of the Ta'rikh Li-1-Khulafa' Wa-1-Wuzara' Wa-l'Ummal Wa-l'Ulama' Wa-1Shu'ara said to be by Abu Ishaq Ibrahim Ibn Abdullah Ibn Abd AlMun' im A1-Hamdani the Qadi of Hama known as Ibn Abi A1-Dam Al-Hamawi .

S.H. Al-Khathlan-University of St. Andrews: A Critical Edition of Raf' Shan Al-Hubshan by Jalal Al-Din Al-Suyuti.

T.A.R. Al-Tickriti-University of St. Andrews: A Critical Edition of Sharh Alfiyat Ibn Malik by Shems AT-Din Hasan b. Qasim al Muradi.

A.A. Brockett-University of St. Andrews: The Background to the Variant Readings of the Qur'an Texts. 
A.E.A. Hussain-University of St. Andrews: Semantic and Syntactic Problems in Translation from Arabic into English with Special Reference to Pre-Islamic Poetry.

A.Y. Jadwat-University of St. Andrews: The Teaching of Arabic to English-speakers.

Helen Shacklady-University of St. Andrews: Politics and Ideology in the Abbasid Revolution.

\section{Appointments, Promotions, Retirements}

Professor R.B. Serjeant-University of Cambridge, retired from the Sir Thomas Adams's Chair of Arabic, December 1981. The Chair will remain vacant indefinitely.

Peter Avery-Director of the Middle East Centre, University of Cambridge

Dr. John Hopk ins-University of Cambridge, retiring and not being replaced.

Hubert Darke-University of Cambridge, in Persian Studies, retiring and not being replaced.

Mrs. A. Bayraktaroglu-University of Cambridge, in Turkish Studies, has finished the statutory five years and will not be replaced.

J.D. Latham-University of Edinburgh, first occupant of the Iraq Chair of Arabic and Islamic Studies, Chairman of the Department of Islamic and Middle Eastern Studies.

W. Montgomery Watt-University of Edinburgh, retired from the Personal Chair of Arabic, September 1979.

L.P. Elwel1-Sutton-University of Edinburgh, retiring from Department of Is lamic and Middle Eastern Studies.

Muhammad Elshayyal-University of Edinburgh, Lecturer in Arabic. 